\title{
THE ECOLOGICAL AMPLITUDE OF GIANT CANE (ARUNDO DONAX VAR. VERSICOLOR) UNDER DIFFERENT WATER LEVEL GRADIENTS
}

\author{
HUANG, H. $.^{*}-\mathrm{CAO}, \mathrm{Y}^{1,2^{*}}-\mathrm{XU}, \mathrm{L} .{ }^{1}$ \\ ${ }^{1}$ College of Geography and Environment, Jiangxi Normal University, Nanchang, Jiangxi \\ 330022, P.R. China \\ ${ }^{2}$ Key Laboratory of Poyang Lake Wetland and Watershed Research, Ministry of Education, \\ Jiangxi Normal University, Nanchang, Jiangxi 330022, P.R. China \\ *Corresponding authors \\ e-mail:yun.cao@163.com,hhx1419@163.com
}

(Received $15^{\text {th }}$ Mar 2021; accepted $19^{\text {th }}$ Jul 2021)

\begin{abstract}
Water level of wetland, one of the most affected ecological factors by climate change, are dominant forces controlling wetland plant growth and distribution in freshwater ecosystems. To analyze the effect of the water level gradients $(-60.74-60 \mathrm{~cm})$ on Arundo donax var. versicolor seedlings in terms of their growth characteristics (base stems diameter, plant height, and biomass), leaf characteristics (leaf length, width, area, number, and moisture content), photosynthetic pigment (chlorophyll, carotenoids), antioxidant enzymes activity (superoxide dismutase, peroxidase and catalase), soluble protein, malondialdehyde and root activity. We determined and quantified the response relationship between $A$. donax var. versicolor and water level based on the Gaussian model. The result showed that underground biomass and $\mathrm{Chl} \mathrm{a}+\mathrm{b}$ were more sensitive indexes to water level. The $\mathrm{Chl} \mathrm{a}+\mathrm{b}$ was more sensitive to the flooded water depth $(61.37 \mathrm{~cm})$, but the underground biomass was influenced by the groundwater depth $(-59.09 \mathrm{~cm})$. The result also showed that the ecological amplitude of the water level for A. donax var. versicolor was -59.09 to $61.37 \mathrm{~cm}$, and the optimal range was -13.87 to $10.44 \mathrm{~cm}$. Therefore, we concluded that it could be a suitable species for ecological restoration of the shallow wetland.
\end{abstract}

Keywords: Arundo donax var. versicolor, indoor potting method, ecological amplitude, Gaussian Model, response mechanism

Abbreviations: A. donax var. versicolor: Arundo donax var. versicolor; SOD: superoxide dismutase $\left(\mathrm{U} \cdot \mathrm{g}^{-1} \cdot \mathrm{min}^{-1}\right)$; POD: peroxidase $\left(\mathrm{U}^{\mathrm{g}} \mathrm{g}^{-1} \cdot \mathrm{min}^{-1}\right)$; CAT: catalase $\left(\mathrm{U} \cdot \mathrm{g}^{-1} \cdot \mathrm{min}^{-1}\right)$; MDA: malondialdehyde (mg.g $\left.\mathrm{g}^{-1}\right)$; Chl-a: chlorophyll a (mg. $\left.\mathrm{g}^{-1}\right)$; Chl-b: chlorophyll b $\left(\mathrm{mg}^{-\mathrm{g}^{-1}}\right)$; Chl a + b: total chlorophyll content $\left(\mathrm{mg} . \mathrm{g}^{-1}\right)$; Chla/b: chlorophyll a/b; Car: carotenoid $\left(\mathrm{mg} \cdot \mathrm{g}^{-1}\right)$

\section{Introduction}

Due to the influence of climate change, severe weather such as drought and heavy precipitation occurs frequently (Hirabayashi et al., 2013), which leads to water level fluctuation in wetlands (Coops et al., 2003). These environmental conditions strongly affect the survival and functioning of wetland plants (Li et al., 2020; Short et al., 2016), and wetland plants have gradually formed their unique survival strategies (Pan et al., 2019) through long-term growth and adaptation to the environment. The adaptation of wetland plants to hydrological processes is not only manifested in the zonal distribution characteristics of water level gradient (Garcia-Baquero et al., 2016; Yin et al., 2010) but also the mechanism of the supply-demand relationship between plant growth and development and water conditions. There is an ecological threshold (Zhao et al., 2007) for the impact of water conditions on wetland plants, namely when water conditions exceed the plant's tolerance range, the plants will grow poorly or even die because they 
cannot properly adjust to water level changes. The change of wetland water level directly affects the composition, diversity, and succession of wetland plant species (Luan et al., 2013). Wetland plants along the water level gradient response research are important to maintain native biodiversity and to design management strategies appropriate for wetland (Magee and Kentula, 2005; Wen et al., 2012). Different water level gradients will affect the soil moisture, air, and affect the physical and chemical properties of soil and the process of vegetation growth environment development, leading to soil environmental change, ultimately affecting the spatial distribution and ecological characteristics of vegetation (Cao et al., 2015).

Arundo donax var. versicolor (A. donax var. versicolor), which is widely introduced and cultivated as a garden foliage plant in China, is a perennial herb in the genus Arundo (Xu et al., 2020). Its plant height can reach several meters, the root system is highly developed, the stem is straight and tidy, the leaves are long and narrow with yellow and white stripes, and the color changes with the season. Because of its strong breeding capacity, flooding resistance, high ornamental value, and many other characteristics, it is widely used in artificial wetland, garden landscape, sewage treatment, papermaking, and other fields.

Previous studies on A. donax var. versicolor mainly focused on garden landscape (Liu et al., 2014), seedling cultivation (Ye and Li, 1994; Zhang et al., 2005), purification of sewage (Xie and Wang, 2009a, b) and photosynthetic characteristics (Yu et al., 2014). In recent years, some studies have explored the effect of drought and rewatering on it $\mathrm{Xu}$ et al., 2020), and its influence on enrichment and migration of heavy metals (Guo et al., 2020; Zhuang et al., 2020). However, studies on water level ecological amplitude of $A$. donax var. versicolor have not been conducted, as well as the response of their growth and physiological characteristics to the water level gradient. Our search in terms of the variation of water level to discuss the response of their growth and physiological characteristics to the water level gradient, and explain the adaptive mechanism of the distribution along the water level gradient of A. donax var. versicolor. Also, we explore the optimal water level ecological amplitude for A. donax var. versicolor, which could offer a theoretical basis for the application of $A$. donax var. versicolor in the restoration of degraded wetland ecosystems.

\section{Materials and methods}

\section{Experimental materials}

The stems of A. donax var. versicolor with uniform size and grow well were collected in May 2018 from Aixi Lake National Wetland Park $\left(115.996333^{\circ} \mathrm{E}, 28.695937^{\circ} \mathrm{N}\right)$ in Jiangxi Province, China. The stems were cut into $5 \mathrm{~cm}$ segments, each segment had a normal side bud, and planted in plastic pots $(35 \times 26 \times 13 \mathrm{~cm})$. The average weight of substrates of each pot was $8 \pm 0.5 \mathrm{~kg}$, the stems were evenly buried depth $2 \mathrm{~cm}$ of soil, and each pot pre-cultured 9 stems. After 30 days of pre-culture, the side buds of stems grew into seedlings, and those with similar growth status were selected for subsequent experiments. The substrates of the experiment were sandy loam mixing evenly soil with sand (volume ratio of 2:1), which had been naturally air-dried and sieved through a $2 \mathrm{~mm}$ sieve. Basic characters of the substrates were analyzed before the experiment (organic matter content: $39 \mathrm{~g} / \mathrm{kg}$; total nitrogen (TN): $18 \mathrm{~g} / \mathrm{kg}$; $\mathrm{pH}$ : 5.4; field water capacity: $30.38 \%$ ). 
The soil in the substrates is swamp soil collected from Aixi Lake National Wetland Park. The water quality indexes of the test water are as follows (Table 1).

Table 1. Average condition of water quality during experiment. Water quality parameters including total nitrogen (TN), (total phosphorus) TP, ammonia nitrogen $\left(\mathrm{NH}_{4}^{+}-\mathrm{N}\right), \mathrm{pH}$ and dissolved oxygen $(D O)$

\begin{tabular}{c|c}
\hline Index & Value \\
\hline $\mathrm{TN}$ & $1.046 \mathrm{mg} / \mathrm{L}$ \\
$\mathrm{TP}$ & $0.033 \mathrm{mg} / \mathrm{L}$ \\
$\mathrm{NH}_{4}{ }^{+}-\mathrm{N}$ & $0.048 \mathrm{mg} / \mathrm{L}$ \\
$\mathrm{pH}$ & 6.71 \\
$\mathrm{DO}$ & $7.18 \mathrm{ml} / \mathrm{L}$ \\
\hline
\end{tabular}

\section{Experimental design}

The experiment was conducted in the glass greenhouse of the Key Laboratory of Poyang Lake Wetland and Watershed Research, Ministry of Education, Nanchang, Jiangxi Province, in China. The pre-cultured A. donax var. versicolor seedlings were transplanted and treated with different water levels. The water level gradient was set up to 16 levels: $-60.74 \mathrm{~cm},-54.39 \mathrm{~cm},-41.67 \mathrm{~cm},-28.95 \mathrm{~cm},-22.60 \mathrm{~cm},-16.24 \mathrm{~cm},-9.88 \mathrm{~cm}$, $-3.52 \mathrm{~cm}, 0 \mathrm{~cm}, 0.29 \mathrm{~cm}, 10 \mathrm{~cm}, 20 \mathrm{~cm}, 30 \mathrm{~cm}, 40 \mathrm{~cm}, 50 \mathrm{~cm}$ and $60 \mathrm{~cm}$. The double pot method was used for positive and negative value treatment. Plastic pots and basins were put into plastic buckets with a height of $70 \mathrm{~cm}$, upper diameter of $57 \mathrm{~cm}$, and lower diameter of $45 \mathrm{~cm}$ for the experiment. Many small holes were drilled in the bottom of each plastic pot, and they were plugged with gauze to make it permeable but block the soil in the pot. The experimental equipment was built shown in Figure 1.
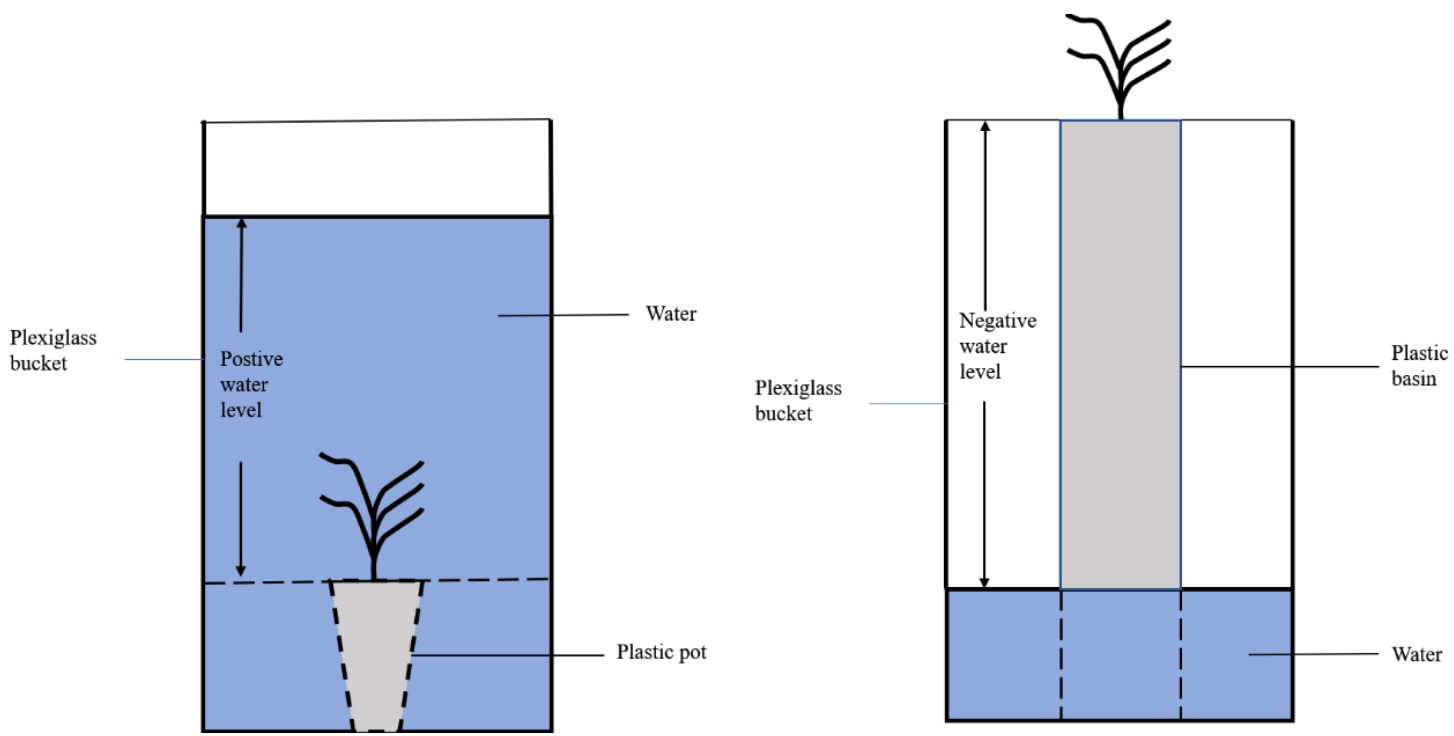

Figure 1. The simulated experimental equipment of water level. Above treatments all use the soil surface as the interface. When the water level gradient is higher than the soil surface, it is usually called water level (Left), which is a positive value; when it is below the soil surface, it is usually called groundwater depth, which is a negative value (Right) 
Three replicated treatments (three pots) were set in the experiment, with 9 seedlings in each pot. When measuring indexes, three seedlings were measured in each pot and repeated three times. To avoid the influence of temperature and solar radiation, the temperature and sunshine duration of glass greenhouse is artificially controlled by air conditioning and sunshade. The average temperature was $23.4 \pm 5^{\circ} \mathrm{C}$, and the sunshine duration was $12 \mathrm{~h}$ every day in the summer. Water changes in each group were observed every day after the experiment began, and water was added to reach the set value. Because the indoor simulation experiment receives less disturbance, no variation in soil surface was detected during the experiment. Other experiment conditions are the same, so any differences in response among A. donax var. versicolor between different treatments could be considered as the result of water level changes.

\section{Indexes determine}

\section{Growth indexes measure}

After the experiment began, plant height, base stems diameter, leaf length, leaf width, leaf number, and leaf area were measured every 7 days (calculated by the coefficient method (Hu, 2015)). Using meter stick measures the plant height. The base stem diameter was measured with vernier caliper and the leaf length and width were measured with a ruler, and Equation 1 was used to calculate leaf area.

$$
S=K \times L \times W
$$

where: $S$ is the blade area, $L$ is the blade length, $W$ is the blade width and $K$ is the coefficient. The coefficient of this type of blade is $1 / 3$.

After the experiment, we need to carefully dig the seedlings from the experiment pot, flush it with distilled water, then use absorbent paper to absorb surface moisture. Separating plant root, stem, and leaf parts with scissors. Using tape to measure root length, using electronic balance to weigh the fresh weight of root, stem, and leaf. Deactivation of enzymes for root, stem, and leaf at $105^{\circ} \mathrm{C}$ for $20 \mathrm{~min}$, and drying them at $75{ }^{\circ} \mathrm{C}$ for $48 \mathrm{~h}$ to constant weight, then measuring their dry weight. The biomass, leaf moisture content, and root-cap ratio were obtained by Equations 2, 3, and 4.

$$
\begin{gathered}
B_{t}=B_{a}+B_{u} \\
R=B_{u} / B_{a} \\
M_{l}=\frac{\left(M_{f^{-}} M_{d}\right)}{M_{f}} \times 100 \%
\end{gathered}
$$

where: $B_{t}$ is total biomass, $B_{a}$ is aboveground biomass, $B_{u}$ is underground biomass, $R$ is root-cap ratio, $M_{l}$ is leaf moisture content, $M_{f}$ is fresh leaf mass, $M_{d}$ is dry leaf mass.

\section{Measurement of physiological indexes}

Leaf samples were respectively collected on days $0,25,50,75$, and 100 after starting the experiment, and the sampling site was the middle part of the plant. Then determine the content of various photosynthetic pigments, soluble protein, Malondialdehyde (MDA), the activity of Superoxide dismutase (SOD), Peroxidase (POD), and Catalase (CAT). Root 
activity was determined on day 100 after treatment. Repeat 3 parallel measurements for each index. The index determination method is Principles and Techniques of Plant Physiological and Biochemical Experiments prepared by Wang (2006).

The content of photosynthetic pigments, including chlorophyll a (Chl-a), chlorophyll $\mathrm{b}(\mathrm{Chl}-\mathrm{b})$, chlorophyll $\mathrm{a}+\mathrm{b}$ content $(\mathrm{Chl} \mathrm{a}+\mathrm{b})$, chlorophyll $\mathrm{a} / \mathrm{b}$ content ratio $(\mathrm{Chl} \mathrm{a} / \mathrm{b})$, and carotenoid (Car), was measured by $95 \%$ absolute ethanol extraction. Grind and extract photosynthetic pigments with $95 \%$ ethanol, and then filter the extract into a $25 \mathrm{~mL}$ brown volumetric flask for constant volume. With $95 \%$ alcohol as the control group, the absorbance of chlorophyll a and chlorophyll $b$ were measured at wavelengths of $665 \mathrm{~nm}$ and $649 \mathrm{~nm}$, respectively, and the absorbance of carotenoids was measured at $470 \mathrm{~nm}$. The content of soluble protein and MDA were measured by Coomassie brilliant blueG250 ratio Color method, thiobarbituric acid method, and root activity was determined by the triphenyltetrazolium chloride method (TTC). The activities of SOD, POD, and CAT were measured by nitrogen blue tetrazole method, guaiacol staining method, and ultraviolet absorption method respectively.

SOD can inhibit the reduction of nitrogen blue tetrazole (NBT) under light conditions, the activity of SOD can be measured. The riboflavin can be reduced by light, and the reduced riboflavin is easily oxidized under aerobic conditions to generate superoxide anion free radicals, and then superoxide anion free radicals can transform the NBT. The azole is reduced to blue methylhydrazone, which has a maximum absorption of $560 \mathrm{~nm}$. In addition, superoxide dismutase has a scavenging effect on superoxide anion free radicals, thereby inhibiting the formation of methylhydrazone. Therefore, after the reaction is completed, the enzyme activity can be judged by the color of the reagent to calculate the enzyme activity. It is known that inhibition of 50\% photochemical reduction of NBT as an enzyme activity unit, SOD is calculated according to Equation 5.

$$
S=\frac{\left(A_{C K}-A_{E}\right) * V}{A_{C K} * W * V_{t} * 0.5}
$$

where: $S$ is the activity of SOD (U/g), $A_{C K}$ is absorbance of control group, $A_{E}$ is the absorbance of the sample tube, $V$ is the total volume of sample solution $(\mathrm{mL}) ; V_{t}$ is the sample dosage $(\mathrm{mL})$ at the time of determination, $W$ is the fresh weight of the sample $(\mathrm{g})$.

Peroxidase (POD) has high activity in plants and is closely related to photosynthesis and respiration. Under the action of POD, hydrogen peroxide reacts with guaiacol to make the enzyme solution dark brown. The dark brown product has a higher absorbance at $470 \mathrm{~nm}$, so in this study, the absorbance change at $470 \mathrm{~nm}$ wavelength was measured. The POD activity is calculated by Equation 6.

$$
P=\left(\Delta A_{470} * V_{T}\right) /\left(W^{*} V_{S} * T^{*} 0.01\right)
$$

where: $P$ is the activity of $\mathrm{POD}\left(\mathrm{U} /(\mathrm{g} \cdot \mathrm{min})^{-1}\right), \Delta A_{470}$ is changes in absorbance during the reaction time, $V_{T}$ is the total volume of sample solution $(\mathrm{mL}), \mathrm{W}$ is the fresh weight of the sample $(\mathrm{g}), V_{S}$ is the sample dosage at the time of determination $(\mathrm{mL}), T$ is reaction time (min).

Hydrogen peroxide $\left(\mathrm{H}_{2} \mathrm{O}_{2}\right)$ was absorbed strongly at a wavelength of $240 \mathrm{~nm}$, catalase (CAT) can decompose hydrogen peroxide, so that the absorbance of the reaction solution decreases with the reaction time. The catalase activity can be measured according to the rate of change in absorbance. The CAT activity is calculated by Equations 7 and 8 . 


$$
\begin{gathered}
C=\frac{\Delta A_{240} * V_{T}}{0.1 * V_{1} * W^{*} T} \\
\Delta A_{240}=A_{S 0^{-}} \frac{A_{S 1}+A_{S 2}}{2}
\end{gathered}
$$

where: $A_{S O}$ is the absorbance of the control group, $A_{S 1}$ and $A_{S 2}$ are the absorbance of the sample group, $V_{T}$ is the total volume of the enzyme solution extract, $V_{l}$ is the volume of the enzyme solution for determination, $T$ is the determination time, $W$ is the fresh weight of the sample.

\section{Calculation of water level ecological amplitude}

The Gaussian Model (Zhang, 2011) was adopted to calculate the water level ecological amplitude. Generally, the relationship between plant species and the environment conforms to the Gaussian model. Namely, a certain environmental factor has a beneficial effect on plant growth, but after threshold, it will inhibit plant growth and development. Equation 9 was used to calculate ecological amplitude.

$$
y=\operatorname{cexp}\left[-0.5(x-u)^{2} / t^{2}\right]
$$

where: $y$ represents an index of biological characteristics of species; $\mathrm{c}$ is the maximum of $\mathrm{y} ; \mathrm{x}$ is the value of the environmental factor, $\mathrm{u}$ is the optimum ecological amplitude of plants; and $t$ is species tolerance. Generally, ecological amplitude of plants were [u$2 \mathrm{t}, \mathrm{u}+2 \mathrm{t}]$, and optimum ecological amplitude of plants were $[\mathrm{u}-\mathrm{t}, \mathrm{u}+\mathrm{t}]$.

\section{Statistical analysis}

Analyzing the data of growth and physiological indexes under different stress treatments by Microsoft-Excel 2010 software. Origin 2019b software was used to draw charts and fit the data to obtain the fitting function relationship of the growth and physiological indexes of $A$. donax var. versicolor.

\section{Results}

\section{Effects of different water levels on morphology characteristics, leaf characteristics, and biomass of A. donax var. versicolor}

The morphological characteristics of $A$. donax var. versicolor varied nonlinearly with the water level. The plant height of roughly showed a rising trend with the increase of water level. The base stems diameter and length of the root system firstly increased and then decreased with the increasing water level. The plant height reached its peak of 107.18 $\mathrm{cm}$ at a water level of $50 \mathrm{~cm}$ and then decreased. The base stems diameter reached a maximum value of $5.52 \mathrm{~mm}$ at the water level of $-9.88 \mathrm{~cm}$. The root length reached the maximum at the water level of $-16.24 \mathrm{~cm}$, which was $83.06 \mathrm{~cm}$. Fitting the water level with the plant height, basal stem, and root system length by quadratic curve fitting. From the fitting effect, only the base stem diameter conforms to the Gaussian model and is normally distributed, $\mathrm{R}^{2}=0.8108$ (Fig. 2). 


\section{a}

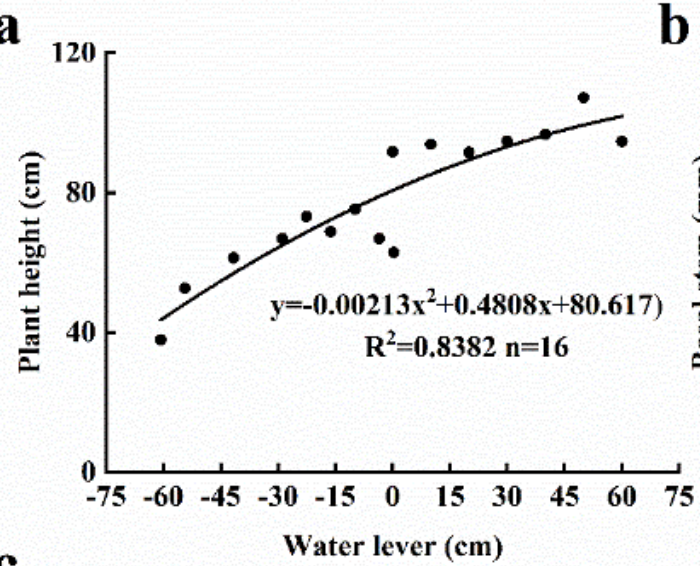

c

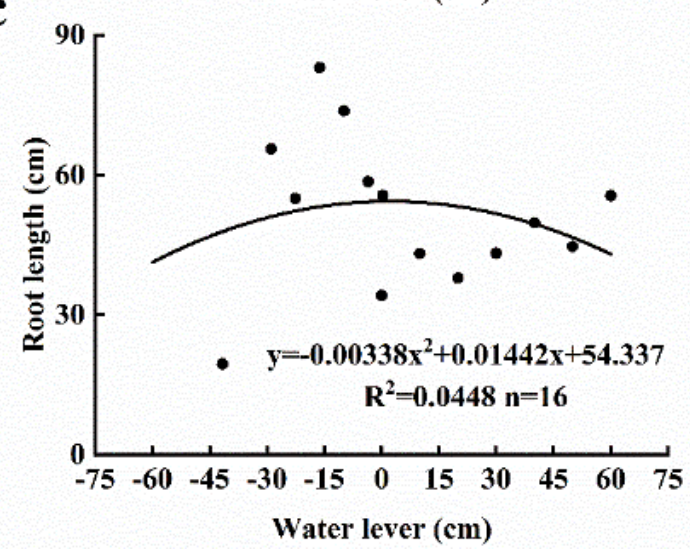

b

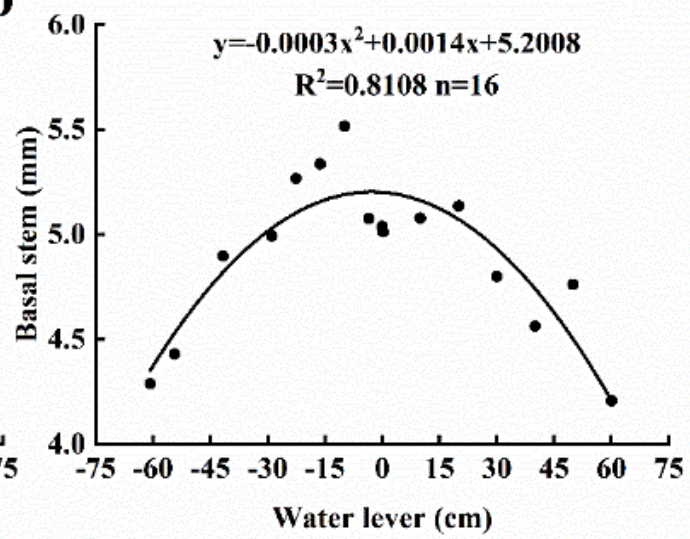

Figure 2. The A. donax var. versicolor growth characteristics vary with the different water level gradient

\section{Effects of different water levels on A. donax var. versicolor leaf characteristics}

The variation of leaf morphological characteristics showed a nonlinear trend under different water levels. The length, width, number, and area of leaves of A. donax var. versicolor firstly increased and then decreased with the increase of water level. The leaf moisture content increased as the water level increased. The leaf length reached its maximum of $33.8 \mathrm{~cm}$ at the water level of $-22.60 \mathrm{~cm}$ and decreased from the peak. At the water level of $-9.88 \mathrm{~cm}$, the blade width has a significant peak of $1.89 \mathrm{~cm}$. At the water level of $50 \mathrm{~cm}$, the leaf number reached the maximum, which was 14.2 . The leaf area reached an obvious peak value of $20.04 \mathrm{~cm}^{2}$ at a water level of $0 \mathrm{~cm}$ and decreased at both ends of this water level. The leaf moisture content roughly showed a rising trend with the increase of water level and reached its maximum of $77.41 \%$ at the water level of $40 \mathrm{~cm}$. The quadratic curve was performed for water level and leaf morphological characteristics. From the perspective of fitting effect, blade length $\left(\mathrm{R}^{2}=0.7181\right)$, blade width $\left(R^{2}=0.715\right)$, leaf number $\left(R^{2}=0.8282\right)$, and leaf area $\left(R^{2}=0.7401\right)$ were in line with the Gaussian model and normally distributed (Fig. 3).

\section{Effects of different water levels on A. donax var. versicolor biomass}

The biomass of $A$. donax var. versicolor varied nonlinearly with water level changes. The aboveground biomass, underground biomass, total biomass, and root-cap ratio increased first and then decreased with the increasing water level. The aboveground 
biomass reached a peak of 5.50 g.plant ${ }^{-1}$ at the water level of $50 \mathrm{~cm}$ and then decreased. The underground biomass at a water level of $0 \mathrm{~cm}$ reached the maximum value, which was 4.57 g.plant ${ }^{-1}$. The total biomass at the water level of $-9.88 \mathrm{~cm}$ reached the highest value of 9.19 g.plant ${ }^{-1}$. The quadratic curve fitting was performed for water level and variety of biomass. For fitting effect, aboveground biomass $\left(\mathrm{R}^{2}=0.7185\right)$, underground biomass $\left(R^{2}=0.7836\right)$, and total biomass $\left(R^{2}=0.8439\right)$ were in line with the Gaussian model and normally distributed, the fitting curve of root-cap ratio has a low fitting degree so that does not accord with the normal distribution (Fig. 4).
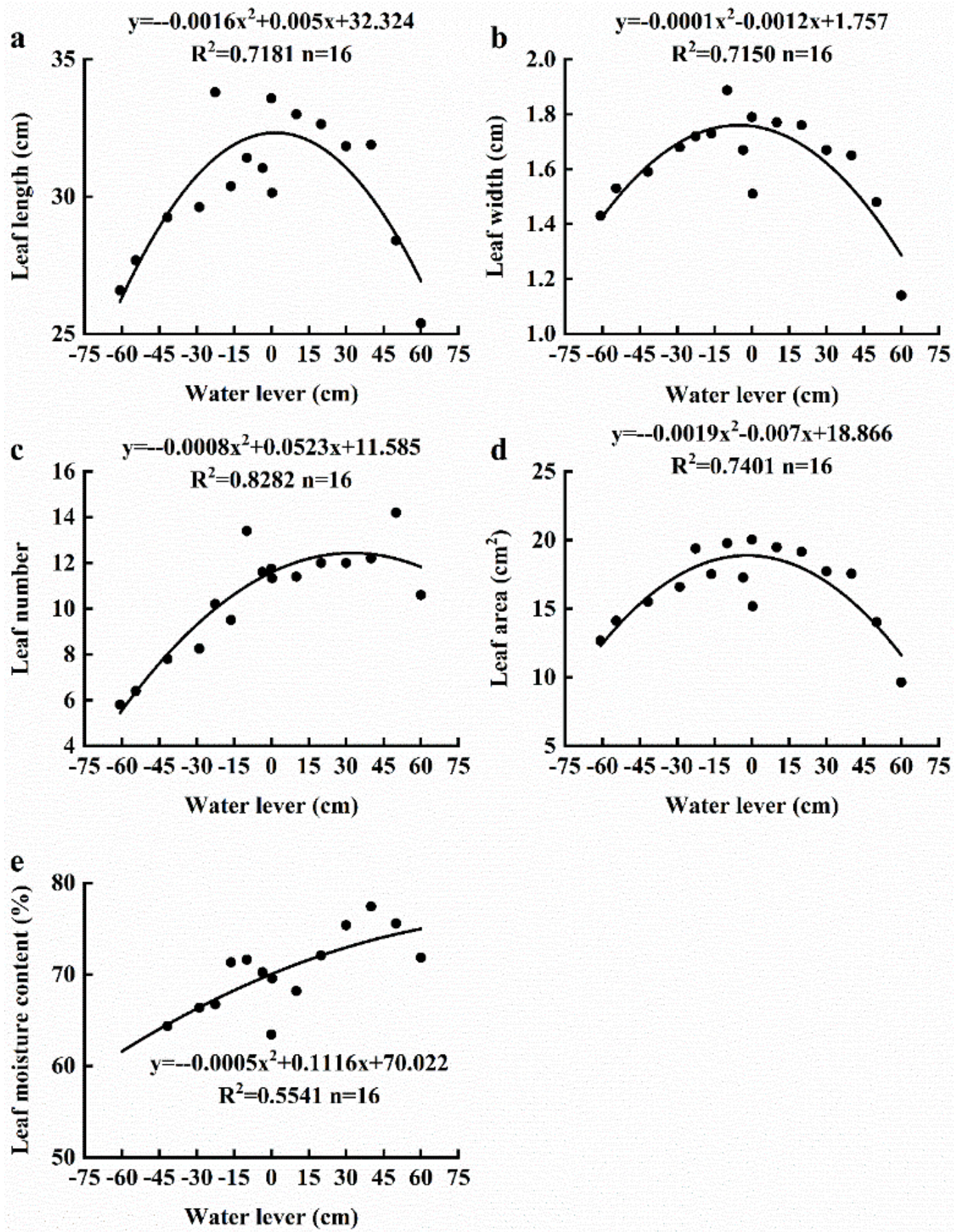

Figure 3. The A. donax var. versicolor leaf characteristics vary with the different water level gradient 

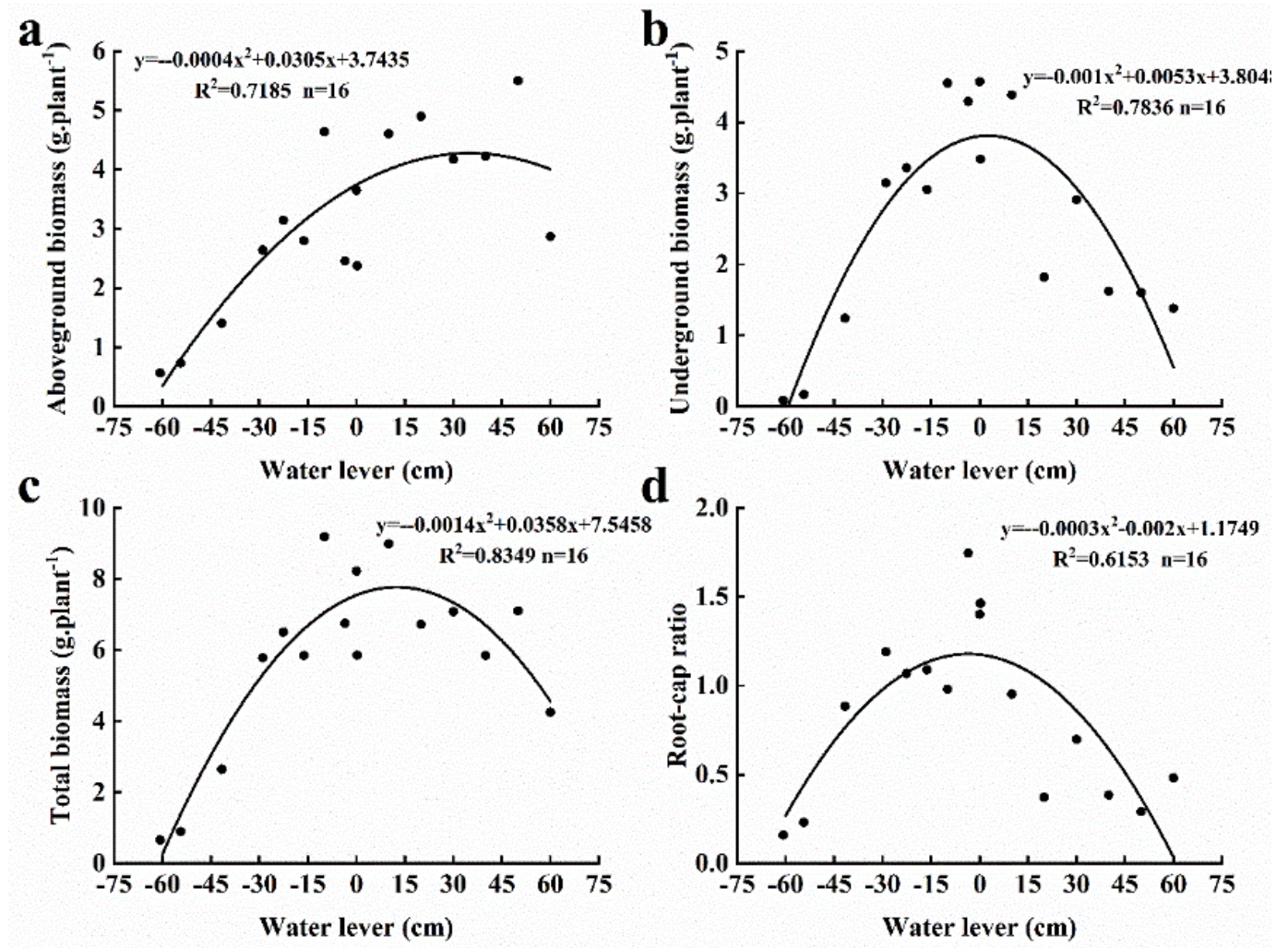

Figure 4. The A. donax var. versicolor biomass varies with the different water level gradient

\section{Effects of different water levels on A. donax var. versicolor photosynthetic pigment}

The contents of Chl-a, Chl-b, and Chl $\mathrm{a}+\mathrm{b}$ in A. donax var. versicolor first increased and then decreased with the increasing water level. The $\mathrm{Chl} a / \mathrm{b}$ roughly increased with the increasing water level, and the contents of Car generally decreased with the increase of the water level. The content of chlorophyll reached its peak at the water level of $3.52 \mathrm{~cm}$, which was $1.07 \mathrm{mg} . \mathrm{g}^{-1}$, and decreased after the maximum value. The content of $\mathrm{Chl}-\mathrm{b}$ reached a maximum value of $0.40 \mathrm{mg} \cdot \mathrm{g}^{-1}$ at the water level of $-16.24 \mathrm{~cm}$. The content of $\mathrm{Chl} \mathrm{a}+\mathrm{b}$ reaches its maximum value of $1.44 \mathrm{mg}^{-\mathrm{g}^{-1}}$ at the water level of -3.52 $\mathrm{cm}$ and has an obvious peak. The water level and photosynthetic pigment content were fitted with a Quadratic curve. From the fitting effect, $\mathrm{Chl} \mathrm{a} / \mathrm{b}$ and Car were not normally distributed. Chl-a $\left(\mathrm{R}^{2}=0.7558\right)$ and $\mathrm{Chl} \mathrm{a}+\mathrm{b}\left(\mathrm{R}^{2}=0.7455\right)$ are in line with the Gaussian model and normally distributed (Fig. 5).

\section{Effects of different water levels on A. donax var. versicolor antioxidant enzymes activity}

The antioxidant enzyme activity of $A$. donax var. versicolor varied nonlinearly with the increasing water level. The activity of SOD, POD, and CAT showed a roughly decreasing trend first and then an increasing trend with the increasing water level. The activity of SOD reached its lowest value of $122.86 \mathrm{U}$. (g.min $)^{-1}$ when the water level is $0.29 \mathrm{~cm}$. The activity of POD has a minimum value of $44.93 \mathrm{U}$. $(\mathrm{g} \cdot \mathrm{min})^{-1}$ when the water level is $0 \mathrm{~cm}$. The activity of CAT has an obvious bottom, which is $1.89 \mathrm{U}$. (g.min) ${ }^{-1}$ at $10 \mathrm{~cm}$. The water level was fitted with SOD, POD, and CAT by quadratic curve fitting. From the fitting effect, the fitting degree of antioxidant enzyme activity was low and did 
not conform to the normal distribution, so the fitting effect was not good that failing to meet the conditions of the Gaussian equation (Fig. 6).
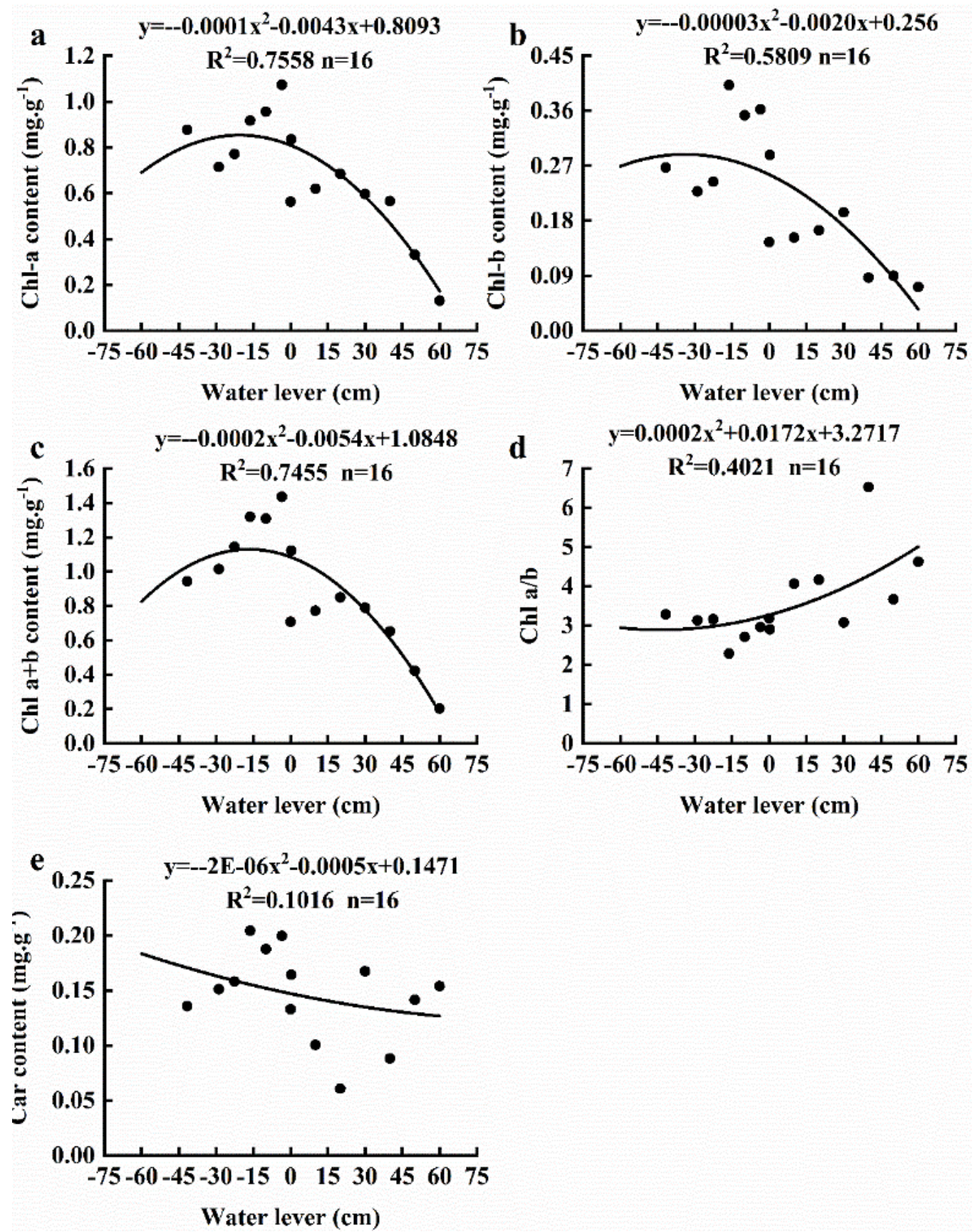

Figure 5. The A. donax var. versicolor photosynthetic pigments vary with the different water level gradient

\section{Effects of different water levels on soluble protein and MDA of A. donax var. versicolor}

The soluble protein, MDA, and root activity of A. donax var. versicolor varied nonlinearly with the water level. The soluble protein and MDA decreased first and then increased with the increasing water level, and the root activity roughly increased with the 
water level. When the water level was $0 \mathrm{~cm}$, the content of soluble protein reached the lowest value of $2.17 \mathrm{mg} \cdot \mathrm{g}^{-1}$. The content of MDA has an obvious minimum value, which is $9.23 \mathrm{mg} \cdot \mathrm{g}^{-1}$ at $0.29 \mathrm{~cm}$ water level. And the root activity increased with the water level raised then reached its maximum value of $0.075 \mathrm{mg}$. $(\mathrm{g} . \mathrm{h})^{-1}$ when the water level reached $50 \mathrm{~cm}$. The water level was fitted with soluble protein, MDA, and root activity by a quadratic curve. From the fitting effect, all indexes did not conform to normal distribution and the fitting effect was poor so that failing to meet the conditions of the Gaussian equation (Fig. 7).
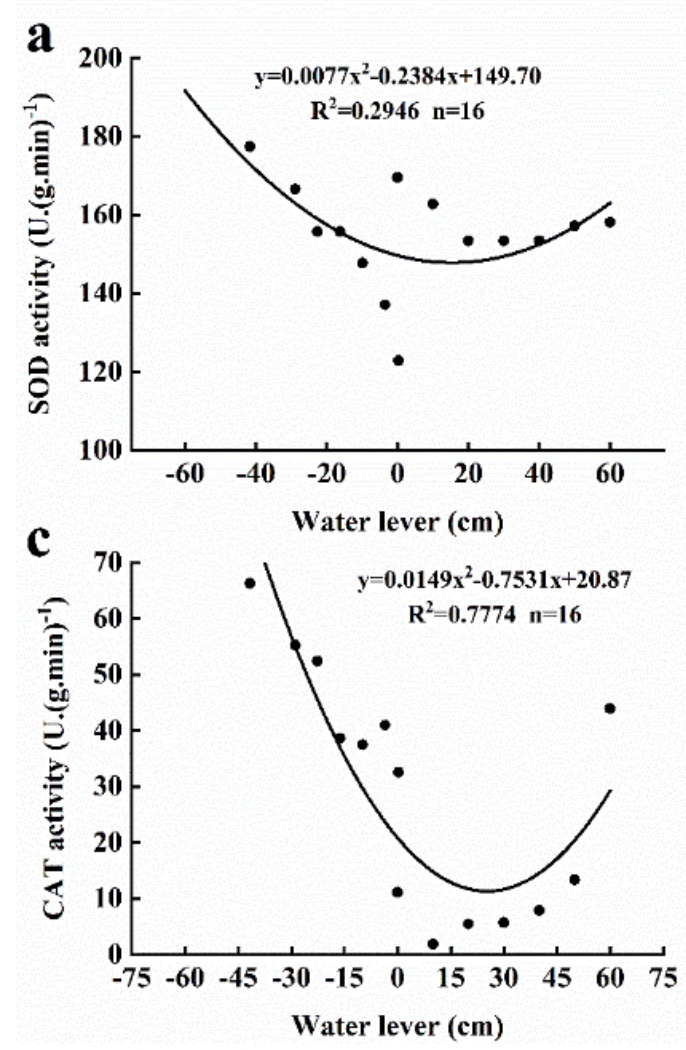

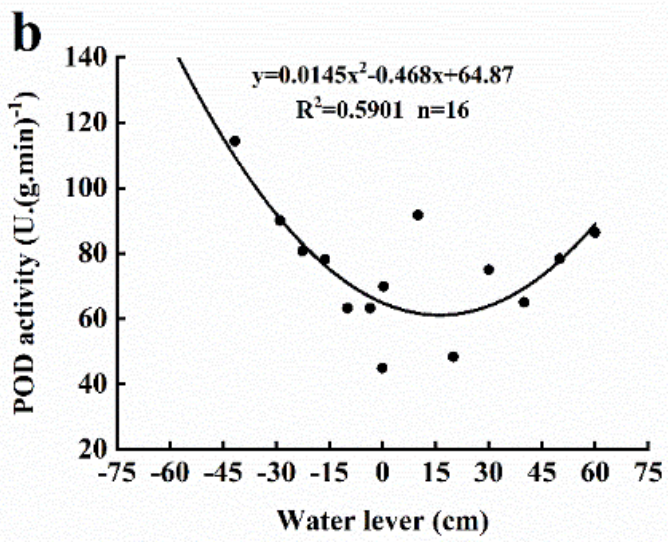

Water lever $(\mathrm{cm})$

Figure 6. The A. donax var. versicolor antioxidant enzyme activity varies with the different water level gradient

\section{The water level ecological amplitude of A. donax var. versicolor}

According to the changes in the growth and physiological characteristics of A. donax var. versicolor under different water level gradients, fitting the water level with base stem diameter, leaf length, leaf width, leaf number, leaf area, aboveground biomass, underground biomass, total biomass, $\mathrm{Chl}-\mathrm{a}$, and $\mathrm{Chl} \mathrm{a}+\mathrm{b}$ by a quadratic curve. The fitting equation formula used was $y=a x^{2}+b x+c$ (where $x$ represents the water level, $\mathrm{cm}$ ) (Table 2). In terms of the transformation relationship between the fitted quadratic curve and the Gaussian model, the Gaussian regression equation of each index can be acquired (Table 3).

According to the fitted Gaussian equation and by using mathematical analysis methods, the optimal water level interval and the limit water level interval of each index can be obtained. Taking the intersection of optimal water level interval and limit water level interval of each index, namely, the lowest value takes the maximum value of the lower 
limit of each interval, and the highest value takes the minimum value of the upper limit of each interval. The obtained intersection is the water level ecological amplitude of $A$. donax var. versicolor, and optimal water level ecological amplitude is about [-13.87, $10.44] \mathrm{cm}$, limit water level ecological amplitude is [-59.09, 61.37] $\mathrm{cm}$ (Table 4). The result indicates that $A$. donax var. versicolor could be grown well when the water level between $-13.87 \mathrm{~cm}$ to $10.44 \mathrm{~cm}$. However, provide that water levels of more than 61.37 $\mathrm{cm}$ or during a time of less than $59.09 \mathrm{~cm}$, The plant cannot maintain normal growth and reproduction. In the process of the experiment, the content of $\mathrm{Chl} \mathrm{a}+\mathrm{b}$ roughly is 0 at the water level of $60 \mathrm{~cm}$, the underground biomass close to 0 at the water level of $-60.74 \mathrm{~cm}$, which is very close to the limit water level of $A$. donax var. versicolor. The results showed that underground biomass and $\mathrm{Chl} \mathrm{a}+\mathrm{b}$ were more sensitive indexes to water level changes during the growth and development of $A$. donax var. versicolor. The $\mathrm{Chl} \mathrm{a}+\mathrm{b}$ was more sensitive to the flooded water depth $(61.37 \mathrm{~cm})$, but the underground biomass was influenced by the groundwater depth $(-59.09 \mathrm{~cm})$.

Table 2. The fitting equations between water level and base stem diameter, leaf length, leaf width, leaf number, leaf area, aboveground biomass, underground biomass, total biomass,

Chlorophyll a (Chl-a), total chlorophyll $($ Chl $a+b)$

\begin{tabular}{c|c|c}
\hline Index & Fitting equation & $\mathbf{R}^{2}$ \\
\hline Base stems diameter $(\mathrm{mm})$ & $\mathrm{y}=-0.0003 \mathrm{x}^{2}+0.0014 \mathrm{x}+5.2008$ & 0.8108 \\
Leaf length $(\mathrm{cm})$ & $\mathrm{y}=-0.0016 \mathrm{x}^{2}+0.005 \mathrm{x}+32.324$ & 0.7181 \\
Leaf width $(\mathrm{cm})$ & $\mathrm{y}=-0.0001 \mathrm{x}^{2}-0.0012 \mathrm{x}+1.757$ & 0.7150 \\
Leaf number $(\mathrm{cm})$ & $\mathrm{y}=-0.0008 \mathrm{x}^{2}+0.0523 \mathrm{x}+11.585$ & 0.8282 \\
Leaf area $\left(\mathrm{cm}^{2}\right)$ & $\mathrm{y}=-0.0019 \mathrm{x}^{2}-0.007 \mathrm{x}+18.866$ & 0.7401 \\
Aboveground biomass $\left(\mathrm{g} \cdot\right.$ plant $\left.^{-1}\right)$ & $\mathrm{y}=-0.0004 \mathrm{x}^{2}+0.0305 \mathrm{x}+3.7435$ & 0.7185 \\
Underground biomass $\left(\mathrm{g} \cdot\right.$ plant $\left.^{-1}\right)$ & $\mathrm{y}=-0.001 \mathrm{x}^{2}+0.0053 \mathrm{x}+3.8048$ & 0.7836 \\
Total biomass $\left(\mathrm{g} \cdot \mathrm{plant} \mathrm{t}^{-1}\right)$ & $\mathrm{y}=-0.0014 \mathrm{x}^{2}+0.0358 \mathrm{x}+7.5458$ & 0.8349 \\
Chl-a (mg $\left.\cdot \mathrm{g}^{-1}\right)$ & $\mathrm{y}=-0.0001 \mathrm{x}^{2}-0.0043 \mathrm{x}+0.8093$ & 0.7558 \\
Chl a $+\mathrm{b}\left(\mathrm{mg} \cdot \mathrm{g}^{-1}\right)$ & $\mathrm{y}=-0.0002 \mathrm{x}^{2}-0.0054 \mathrm{x}+1.0848$ & 0.7455 \\
\hline
\end{tabular}

Table 3. Gaussian regression equations of growth and physiological indexes of A. donax var. versicolor. Indexes including base stem diameter, leaf length, leaf width, leaf number, leaf area, aboveground biomass, underground biomass, total biomass, Chlorophyll a (Chla), total chlorophyll $(\mathrm{Chl} a+b)$

\begin{tabular}{c|c}
\hline Index & Gaussian regression equation \\
\hline Base stems diameter $(\mathrm{mm})$ & $\mathrm{y}=5.2024 \exp \left[-0.5(\mathrm{x}+2.3334)^{2} / 65.84352\right]$ \\
Leaf length $(\mathrm{cm})$ & $\mathrm{y}=32.3279 \exp \left[-0.5(\mathrm{x}-1.5625)^{2} / 71.07212\right]$ \\
Leaf width $(\mathrm{cm})$ & $\mathrm{y}=1.7551 \exp \left[-0.5(\mathrm{x}-1.5625)^{2} / 71.07212\right]$ \\
Leaf number $(\mathrm{cm})$ & $\mathrm{y}=12.4398 \exp \left[-0.5(\mathrm{x}-32.6875)^{2} / 62.3493\right]$ \\
Leaf area $\left(\mathrm{cm}^{2}\right)$ & $\mathrm{y}=18.8725 \exp \left[-0.5(\mathrm{x}+1.8421)^{2} / 49.83192\right]$ \\
Aboveground biomass $\left(\mathrm{g} \cdot\right.$ plant $\left.^{-1}\right)$ & $\mathrm{y}=4.3249 \exp \left[-0.5(\mathrm{x}-38.125)^{2} / 51.9912\right]$ \\
Underground biomass $\left(\mathrm{g} \cdot \mathrm{plant}^{-1}\right)$ & $\mathrm{y}=3.8118 \exp \left[-0.5(\mathrm{x}-2.65)^{2} / 30.872\right]$ \\
Total biomass $\left(\mathrm{g} \cdot \mathrm{plant}^{-1}\right)$ & $\mathrm{y}=7.7773 \exp \left[-0.5(\mathrm{x}-12.7858)^{2} / 37.26662\right]$ \\
Chl-a $\left(\mathrm{mg} \cdot \mathrm{g}^{-1}\right)$ & $\mathrm{y}=0.8555 \exp \left[-0.5(\mathrm{x}+21.5)^{2} / 46.24732\right]$ \\
Chl a $+\mathrm{b}\left(\mathrm{mg} \cdot \mathrm{g}^{-1}\right)$ & $\mathrm{y}=1.1213 \exp \left[-0.5(\mathrm{x}+13.5)^{2} / 23.93752\right]$ \\
\hline
\end{tabular}


Table 4. The water level ecological amplitude of A. donax var. versicolor calculated by Gaussian Model

\begin{tabular}{c|c|c|c|c|c}
\hline Index & $\mathbf{c}$ & $\mathbf{u}$ & $\mathbf{t}$ & {$[\mathbf{u}-\mathbf{t}, \mathbf{u}+\mathbf{t}]$} & {$[\mathbf{u}-\mathbf{2 t}, \mathbf{u}+\mathbf{2 t}]$} \\
\hline Base stems diameter $(\mathrm{mm})$ & 5.20 & -2.33 & 65.84 & {$[-68.18,63.51]$} & {$[-134.02,129.35]$} \\
Leaf length $(\mathrm{cm})$ & 32.33 & 1.56 & 71.07 & {$[-69.51,72.63]$} & {$[-140.58,143.71]$} \\
Leaf width $(\mathrm{cm})$ & 1.76 & 1.56 & 71.07 & {$[-69.51,72.63]$} & {$[-140.58,143.71]$} \\
Leaf number $(\mathrm{cm})$ & 12.44 & 32.69 & 62.35 & {$[-29.66,95.04]$} & {$[-92.01,157.39]$} \\
Leaf area $\left(\mathrm{cm}^{2}\right)$ & 18.87 & -1.84 & 49.83 & {$[-51.67,47.99]$} & {$[-101.51,97.82]$} \\
Aboveground biomass $\left(\mathrm{g} \cdot\right.$ plant $\left.^{-1}\right)$ & 4.32 & 38.13 & 51.99 & {$[-13.87,90.12]$} & {$[-65.86,142.12]$} \\
Underground biomass $\left(\mathrm{g} \cdot\right.$ plant $\left.^{-1}\right)$ & 3.81 & 2.65 & 30.87 & {$[-28.22,33.52]$} & {$[-59.09,64.39]$} \\
Total biomass $\left(\mathrm{g} \cdot\right.$ plant $\left.^{-1}\right)$ & 7.78 & 12.79 & 37.27 & {$[-24.48,50.05]$} & {$[-61.75,87.32]$} \\
Chl-a (mg.g $\left.{ }^{-1}\right)$ & 0.8555 & -21.5 & 46.25 & {$[-67.75,24.75]$} & {$[-113.99,70.99]$} \\
Chl a + b $\left(\mathrm{mg} \cdot \mathrm{g}^{-1}\right)$ & 1.12 & -13.5 & 23.94 & {$[-37.44,10.44]$} & {$[-88.37,61.37]$} \\
\hline \multicolumn{2}{c|}{ Calculation results (cm) } & & {$[-13.87,10.44]$} & {$[-59.09,61.37]$} \\
\hline
\end{tabular}
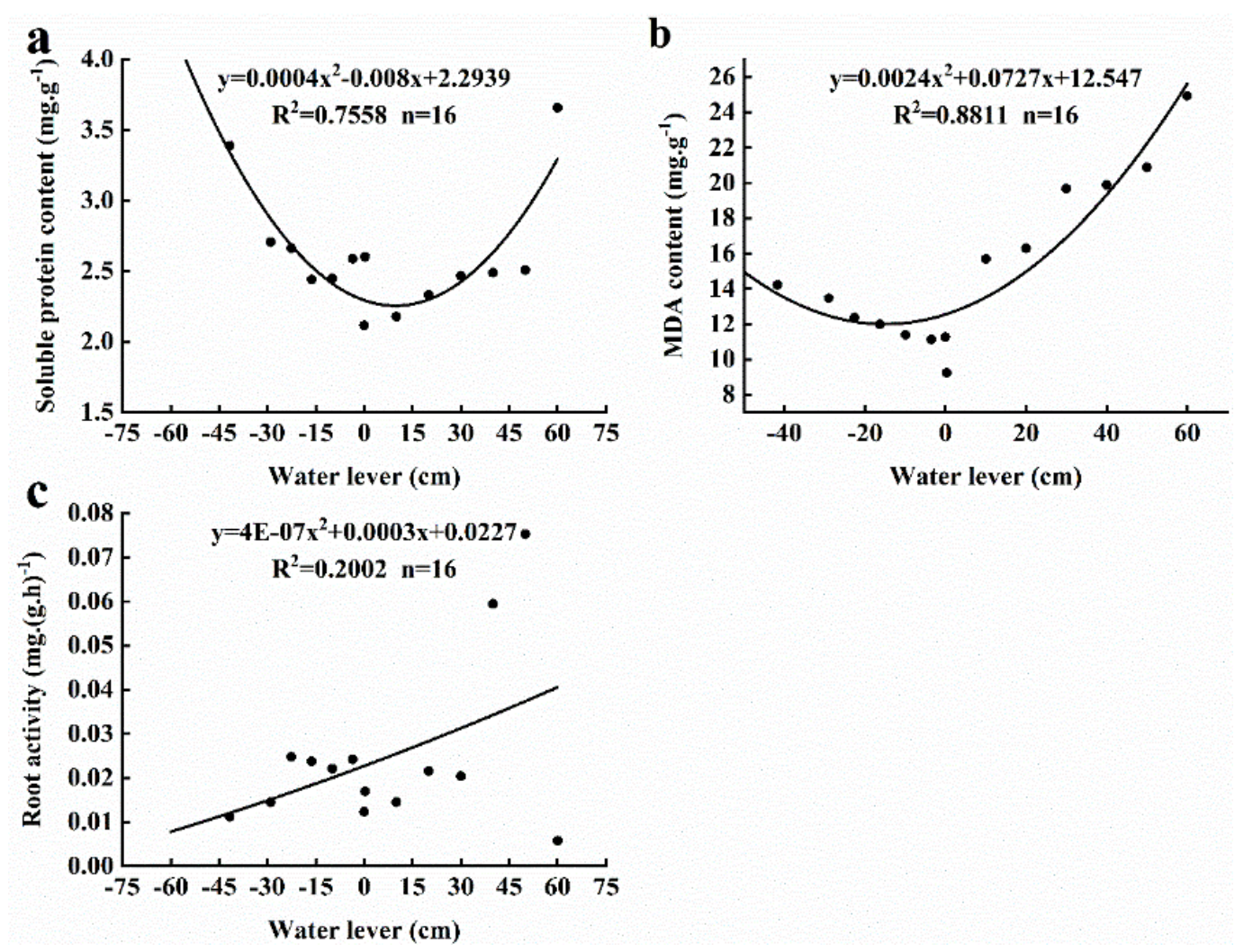

Figure 7. The A. donax var. versicolor soluble protein, MDA, and root activity vary with the different water level gradient

\section{Discussion}

\section{Responses of morphology to water level changes}

The research results showed that base stems diameter, root length, leaf length, leaf width, leaf number, leaf area, aboveground biomass, underground biomass, total biomass, and root-cap ratio all increased first and then decreased with the increasing water level, 
and reached their maximum value at the water level of -22.60 to $0 \mathrm{~cm}$. But the plant height, root length, leaf moisture content generally show a trend of increasing with the rise of water level. Due to its special hollow structure, A. donax var. versicolor can adapt to environmental pressures more effectively (Okada et al., 2009). Drought restricts plant metabolism leads to poor growth (Cruz et al., 2019; Voronin et al., 2019), therefore, when the water level increases to optimum water level, the morphological indexes of plants increase accordingly. Feng has compared the two groundwater levels of Carex cinerascens, $10 \mathrm{~cm}$, and $20 \mathrm{~cm}$, and found that $10 \mathrm{~cm}$ groundwater level was overall more suitable for plant growth resulting in higher stem height and biomass (Feng et al., 2020). Under flooded anaerobic conditions, emergent plants will adjust their survival strategies, such as developing shallow roots, reducing underground biomass, and increasing aboveground biomass to accelerate the growth of plant height. The root-cap ratio increases with the decrease of underground biomass and the increase of above-ground biomass. In addition to adjustment of biomass allocation, the plant height and basal stem also changed, and the plants become more slender. The change of plant morphology helps it alleviate the anaerobic condition by absorbing more oxygen transport to roots. The plant leaves also respond significantly to drought and flooding stress, which are mainly manifested as leaf shedding, wilting, and reduced area. The reasonable explanation is that under stress conditions, the nutrients in the leaves are consumed for respiration and cannot be effectively supplemented, leading to the decrease of the leaves' biomass. It is conducted that appropriate drought was conducive to the growth and biomass accumulation of $A$. donax var. versicolor. However, all morphological characteristics decreased with the decrease or increase of water level. It indicates that in the environment of excessive drought and flooding, A. donax var. versicolor would reduce individuals to adapt to adversity, which is similar to the conclusion of the study of Carex cinerascens (Yang et al., 2015).

\section{Responses of chlorophyll, antioxidant enzyme activity to water level changes}

Our studies indicate that the contents of Chl-a and Chl $\mathrm{a}+\mathrm{b}$ increased first then decreased with the increasing water level and reached their maximum at the water level of $-3.52 \mathrm{~cm}$. The photosynthetic pigment is the most important material component of plant photosynthesis. Our result shows that severe drought and flooding will inhibit the synthesis of photosynthetic pigment and reduce the chlorophyll content of plants, which is consistent with some previous research (Chen et al., 2010; Parolin et al., 2010). Flooding is known to affect photosynthesis through changes in stomatal conductance, many wetland species initially close stomata in response to soil flooding ( $\mathrm{Li}$ et al., 2010). The reasonable explanation for the decrease in chlorophyll content under long-term flooded conditions is that due to oxygen deficiency, this anaerobic condition will inhibit the synthesis of photosynthetic pigments in wetland plants, and ultimately lead to premature leaf senescence (Zhang et al., 2020). In addition to hypoxia, some scholars believe that lack of nitrogen leads to plant leaf death (Li et al., 2006). Along with the inhibition of plants growth, the suppression of photosynthesis is also a typical response to drought stress (Chaves et al., 2007; Voronin et al., 2019). In normal circumstances, the transpiration of plants is relatively strong, but plants under drought stress have to close their stomata to reduce water loss. Decreased stomatal conductance will affect a series of physiological effects, including the synthesis of photosynthetic pigments. Therefore, tomata closure may be the main factor resulting in the reduction of photosynthetic pigments under drought and flooding. 
To resist the damage caused by high levels of active oxygen caused by drought, plants have evolved enzymatic and non-enzymatic active oxygen scavenging systems to maintain the optimal active oxygen balance required for cell metabolism (Gill and Tuteja, 2010; Hou et al., 2021). The key enzymes include SOD, CAT, and POD. SOD (Alscher et al., 2002) is the first line of defense against active oxygen damage in the plant's antioxidant system, converting superoxide-free radicals into $\mathrm{H}_{2} \mathrm{O}_{2}$. CAT can remove $\mathrm{H}_{2} \mathrm{O}_{2}$, which converts it into oxygen and water through a catalytic reaction (Willekens et al., 1997). POD can assist in removing $\mathrm{H}_{2} \mathrm{O}_{2}$ produced by the SOD disproportionation reaction (Reddy et al., 2004). Our study result indicates that antioxidant enzyme activity decreases first and then increases with the increasing water level, the lowest value reached when the water level was roughly $-9.88-0 \mathrm{~cm}$. In this condition, the A. donax var. versicolor can maintain normal growth and development and produces less active oxygen. However, in severe drought and deeper submergence water depth, active oxygen of plants produces excessively (Arbona et al., 2008; Tahkokorpi et al., 2007), so that activates the antioxidant enzyme system in the $A$. donax var. versicolor. Then antioxidant enzyme activity will increase and eliminate the damage that active oxygen for the plants (Li et al., 2013b; Rangani et al., 2018). We found that SOD, POD, and CAT all show an upward trend under stress consistent with the antioxidant enzyme study results about Carex duriuscula. Their study result indicates that antioxidant enzymatic activity as components of the drought tolerance mechanism in Carex duriuscula (Hou et al., 2021).

\section{Responses of MDA, soluble protein, and root activity to water level changes}

Flooding stress causes a low light environment, restricts gas diffusion, increases lipid peroxidation of leaf cell membranes, damages the protective enzyme system in the body, degrades chlorophyll, accumulates malondialdehyde content, and decreases photosynthetic rate (Pan and Xue, 2012). MDA is the final product of membrane lipid peroxidation. It is usually used as a lipid peroxidation indicator to indicate the degree of cell membrane lipid peroxidation and the strength of the plant's response to adversity stress (Li et al., 2013a). In our study, when the water level is too low or too high, the MDA content is at a relatively high level and its lowest value at $0 \mathrm{~cm}$ water level. The response of MDA concentration of Phragmites communis seedling to flooding has been studied, and it increases with flooding and flooded duration (Bai et al., 2012), which is similar to us. The soluble protein as a kind of osmotic adjustment substance can be actively accumulated to protect the cell membrane and reduce peroxide damage to plants when under stronger stress (Guan et al., 2015). The soluble protein content reached the minimum value at a water level of $0 \mathrm{~cm}$, and the content of soluble protein decreased first and then increased with the increase of water level. It suggests that the stress degree for A. donax var. versicolor is relatively small when the water level at $0 \mathrm{~cm}$, but the cell membrane was damaged under flooding and drought stress. During a severe drought and flood degree, the soluble protein content of $A$. donax var. versicolor was high. The results showed that soluble protein played an important role in reducing peroxidation damage. The root activity roughly shows an upward trend with higher water levels. It shows that the root activity is inhabited under drought conditions. The response of soluble protein and root activity to drought stress was similar to other herbaceous plants, in distance, the study of the responses of typical annual herbaceous plants to drought stress (Xi et al., 2021). 


\section{The water level ecological amplitude of A. donax var. versicolor}

The results indicated that the water level ecological amplitude of A. donax var. versicolor was $[-59.09 \mathrm{~cm}, 61.37 \mathrm{~cm}]$, the optimum water level was $[-13.87 \mathrm{~cm}$, $10.44 \mathrm{~cm}$ ]. Namely, it cannot normally grow when the water level is below $59.09 \mathrm{~cm}$ or higher than $61.37 \mathrm{~cm}$. For the A. donax var. versicolor, low water level is the most suitable water level. The result also shows that the plant has poor waterlogging resistance and stronger drought resistance. It is consistent with $A$. donax var. versicolor waterlogging resistance studies done by $\mathrm{Xu}$ Jie (Xu and Tu, 2014). There are also many studies on other helophyte plants. For example, the optimal ecological water level of Carex lasiocarpa was found to be 13.45 to $29.78 \mathrm{~cm}$ (Luan et al., 2013). The most suitable ecological amplitude of water level of Calamagrostis angustifolia, Carex lasiocaropa and $C$. pseudocuraica were: [4.46 cm, $20.04 \mathrm{~cm}],[8.30 \mathrm{~cm}, 28.40 \mathrm{~cm}]$ and $[40.87 \mathrm{~cm}, 48.71 \mathrm{~cm}]$ (Xue et al., 2020). The Phragmites australis as a common species for studying physiological response models to global change has been found that the survival, physiology, and growth of Phragmites australis are less affected by submersion than many other wetland plants. That is, it has a wider ecological amplitude of water level.

By comparing their ecological amplitude, we found that A. donax var. versicolor is more drought-resistant than Carex lasiocarpa, but its ability to resist waterlogging is worse. The result can provide some reference for the cultivation and propagation of $A$. donax var. versicolor in wetland parks in the future.

\section{Conclusions}

This research through the indoor pot method and setting different water level gradients, observing and studying the growth and physiological indexes of the A. donax var. versicolor under different water level conditions, and exploring its water level ecological amplitude. The results showed that underground biomass and $\mathrm{Chl} \mathrm{a}+\mathrm{b}$ were more sensitive indexes to water level changes during the growth and development of $A$. donax var. versicolor. The $\mathrm{Chl} \mathrm{a}+\mathrm{b}$ was more sensitive to the flooded water depth $(61.37 \mathrm{~cm})$, but the underground biomass was influenced by the groundwater depth $(-59.09 \mathrm{~cm})$.

Calculated by the Gaussian model, the water level ecological amplitude of $A$. donax var. versicolor was $[-59.09,61.37] \mathrm{cm}$, and the optimal water level was $[-13.87,10.44] \mathrm{cm}$. The results suggest that when the water level was lower than about $-59.09 \mathrm{~cm}$ or higher than $61.37 \mathrm{~cm}$, the seedlings could not grow normally, and the most suitable area for $A$. donax var. versicolor was the shallow water. Therefore, the plant could be a suitable species for wetland ecological restoration and garden landscaping.

The study obtained the water level ecological amplitude of $A$. donax var. versicolor based on different static water levels. However, some seasonal lakes and wetlands (e.g. Poyang Lake in China) water level fluctuates greatly (Wang et al., 2013), the short-time water level variety has a huge impact on the wetland plants. Therefore, future research on the water level of $A$. donax var. versicolor should focus on quantitative its tolerance to water level fluctuations, it is the key to further proving A. donax var. versicolor can successfully be used for wetland ecological restoration.

Acknowledgments. This research was supported by the National Natural Scientific Foundation of China (42061021), and the Natural Scientific Foundation of Jiangxi Province (20181BAB203021). 
Conflicts of competing interests. The authors declare that they have no known competing financial interests or personal relationships that could have appeared to influence the work reported in this paper.

\section{REFERENCES}

[1] Alscher, R. G., Erturk, N., Heath, L. S. (2002): Role of superoxide dismutases (SODs) in controlling oxidative stress in plants. - Journal of Experimental Botany 53(372): 13311341. DOI: $10.1093 /$ jexbot/53.372.1331.

[2] Arbona, V., Hossain, Z., Lopez-Climent, M. F., Perez-Clemente, R. M., Gomez-Cadenas, A. (2008): Antioxidant enzymatic activity is linked to waterlogging stress tolerance in citrus. - Physiol Plant 132(4): 452-466. DOI: 10.1111/j.1399-3054.2007.01029.x.

[3] Bai, X., Chen, K. N., Ren, K. X., Huang, W., Chen, X. M., Yang, H. (2012): Physiological response of Phragmites communis seedling to two types of sediment under submergence and its recovering growth. - Journal of Lake Sciences 24(04): 562-570.

[4] Cao, Y., Guo, Z., Yang, Y., Wang, G., Xie, Z. (2015): The ecological amplitude of Acorus calamus young shoots under water level gradient. - Polish Journal of Ecology 63(4): 585592. DOI: 10.3161/15052249PJE2015.63.4.010.

[5] Chaves, M., Flexas, J., Pinheiro, C. (2007): Photosynthesis under drought and salt stress regulation mechanisms from the whole plant to cell. - Photosynthesis Research 91(2-3): 300-300.

[6] Chen, H., Zamorano, M. F., Ivanoff, D. (2010): Effect of flooding depth on growth, biomass, photosynthesis, and chlorophyll fluorescence of Typha domingensis. - Wetlands 30(5): 957-965. DOI: 10.1007/s13157-010-0094-y.

[7] Coops, H., Beklioglu, M., Crisman, T. L. (2003): The role of water-level fluctuations in shallow lake ecosystems - workshop conclusions. - Hydrobiologia 506(1): 23-27.

[8] Cruz, Y. D. C., Martins Scarpa, A. L., Pereira, M. P., De Castro, E. M., Pereira, F. J. (2019): Growth of Typha domingensis as related to leaf physiological and anatomical modifications under drought conditions. - Acta Physiologiae Plantarum 41(5). DOI: 10.1007/s11738-019-2858-1.

[9] Feng, W., Mariotte, P., Xu, L., Buttler, A., Bragazza, L., Jiang, J., Santonja, M. (2020): Seasonal variability of groundwater level effects on the growth of Carex cinerascens in lake wetlands. - Ecology and Evolution 10(1): 517-526. DOI: 10.1002/ece3.5926.

[10] Garcia-Baquero, G., Silvertown, J., Gowing, D. J., Valle, C. J. (2016): Dissecting the hydrological niche: soil moisture, space and lifespan. - Journal of Vegetation Science 27(2): 219-226. DOI: $10.1111 /$ jvs.12353.

[11] Gill, S. S., Tuteja, N. (2010): Reactive oxygen species and antioxidant machinery in abiotic stress tolerance in crop plants. - Plant Physiology and Biochemistry 48(12): 909-930. DOI: 10.1016/j.plaphy.2010.08.016.

[12] Guan, G. F., Wang, Y. S., Cheng, H., Jiang, Z. Y., Fei, J. (2015): Physiological and biochemical response to drought stress in the leaves of Aegiceras corniculatum and Kandelia obovata. - Ecotoxicology 24(7-8): 1668-1676. DOI: 10.1007/s10646-015-14704.

[13] Guo, R. F., Li, G. J., Liu, X. M., Huang, T., Lin, Y. M., Wu, C. Z., Li, J. (2020): Accumulation and migration characteristics of heavy metal in Thalia dealbata and Arundo donax var. versicolor in constructed wetland of Wuyishan City. - Journal of Plant R esources and Environment 29(04): 28-35.

[14] Hirabayashi, Y., Mahendran, R., Koirala, S., Konoshima, L., Yamazaki, D., Watanabe, S., Kim, H., Kanae, S. (2013): Global flood risk under climate change. - Nature Climate Change 3(9): 816-821. DOI: 10.1038/NCLIMATE1911.

[15] Hou, P., Wang, F., Luo, B., Li, A., Wang, C., Shabala, L., Ahmed, H. A. I., Deng, S., Zhang, H., Song, P., Zhang, Y., Shabala, S., Chen, L. (2021): Antioxidant enzymatic activity and 
osmotic adjustment as components of the drought tolerance mechanism in Carex duriuscula. - Plants-Basel 10(3). DOI: 10.3390/plants10030436.

[16] Hu, L. (2015): Research on adjusted coefficient method for leaf area measurement and its error. - Chinese Agricultural Science Bulletin 31(05): 228-233.

[17] Li, R. H., Guo, P. G., Michael, B., Stefania, G., Salvatore, C. (2006): Evaluation of chlorophyll content and fluorescence parameters as indicators of drought tolerance in barley. - Agricultural Sciences in China 5(10): 751-757.

[18] Li, M., Hou, G., Yang, D., Deng, G., Li, W. (2010): Photosynthetic traits of Carex cinerascens in flooded and nonflooded conditions. - Photosynthetica 48(3): 370-376. DOI: 10.1007/s11099-010-0048-x.

[19] Li, F., Qin, Y., X., Xie, H., Y., Chen, X. S., Hu, J. Y., Liu, Y. Y., Hou, Z. Y. (2013a): Physiological mechanisms for plant distribution pattern: responses to flooding and drought in three wetland plants from Dongting Lake, China. - Limnology 14(1): 71-76. DOI: 10.1007/s10201-012-0386-4.

[20] Li, Y., Zhang, S., Jiang, W., Liu, D. (2013b): Cadmium accumulation, activities of antioxidant enzymes, and malondialdehyde (MDA) content in Pistia stratiotes L. - Environ Sci Pollut Res Int 20(2): 1117-1123. DOI: 10.1007/s11356-012-1054-2.

[21] Li, L., Ding, M., Jeppesen, E. (2020): Variation in growth, reproduction, and resource allocation in an aquatic plant, Vallisneria spinulosa: the influence of amplitude and frequency of water level fluctuations. - Aquatic Sciences 82(4): 81-93. DOI: https://doi.org/10.1007/s00027-020-00754-8.

[22] Liu, B., Shen, H., Xu, F., Chen, W. (2014): Ornamental-adaptability evaluation of ornamental grasses in Southeastern coastal region of Shandong. - Pratacultural Science 31(12): 2221-2229. DOI: 10.11829 \j.issn.1001-0629.2014-0046.

[23] Luan, Z., Wang, Z., Yan, D., Liu, G., Xu, Y. (2013). The ecological response of Carex lasiocarpa community in the riparian wetlands to the environmental gradient of water depth in Sanjiang Plain, Northeast China. - Scientific World Journal 2013. DOI: http://dx.doi.org/10.1155/2013/402067.

[24] Magee, T. K., Kentula, M. E. (2005): Response of wetland plant species to hydrologic conditions. - Wetlands Ecology and Management 13(2): 163-181. DOI: 10.1007/s11273004-6258-x.

[25] Okada, M., Grewell, B. J., Jasieniuk, M. (2009): Clonal spread of invasive Ludwigia hexapetala and L. grandiflora in freshwater wetlands of California. - Aquatic Botany 91(3): 123-129. DOI: 10.1016/j.aquabot.2009.03.006.

[26] Pan, L., Xue, L. (2012): Plant physiological mechanisms in adapting to waterlogging stress: a review. - Chinese Journal of Ecology 31(10): 2662-2672.

[27] Pan, Y., Ellen, C., Bodegom, P. M. v. (2019): Are ecophysiological adaptive traits decoupled from leaf economics traits in wetlands? - Functional Ecology 33(7): 1202-1210. DOI: $10.1111 / 1365-2435.13329$.

[28] Parolin, P., Lucas, C., Piedade, M. T., Wittmann, F. (2010): Drought responses of floodtolerant trees in Amazonian floodplains. - Ann Bot 105(1): 129-139. DOI: 10.1093/aob/mcp258.

[29] Rangani, J., Panda, A., Patel, M., Parida, A. K. (2018): Regulation of ROS through proficient modulations of antioxidative defense system maintains the structural and functional integrity of photosynthetic apparatus and confers drought tolerance in the facultative halophyte Salvadora persica L. - J Photochem Photobiol B 189: 214-233. DOI: 10.1016/j.jphotobiol.2018.10.021.

[30] Reddy, A. R., Chaitanya, K. V., Vivekanandan, M. (2004): Drought-induced responses of photosynthesis and antioxidant metabolism in higher plants. - Journal of Plant Physiology 161(11): 1189-1202. DOI: 10.1016/j.jplph.2004.01.013.

[31] Short, F. T., Kosten, S., Morgan, P. A., Malone, S., Moore, G. E. (2016): Impacts of climate change on submerged and emergent wetland plants. - Aquatic Botany 135: 3-17. DOI: http://dx.doi.org/10.1016/j.aquabot.2016.06.006. 
[32] Tahkokorpi, M., Taulavuori, K., Laine, K., Taulavuori, E. (2007): After-effects of droughtrelated winter stress in previous and current year stems of Vaccinium myrtillus L. Environmental and Experimental Botany 61(1): 85-93. DOI: 10.1016/j.envexpbot.2007.03.003.

[33] Voronin, P. Y., Maevskaya, S. N., Nikolaeva, M. K. (2019): Physiological and molecular responses of maize (Zea mays L.) plants to drought and rehydration. - Photosynthetica 57(3): 850-856. DOI: 10.32615/ps.2019.101.

[34] Wang, X. K. (2006): Principles and Techniques of Plant Physiological and Biochemical Experiments. - Higher Education Press, Beijing.

[35] Wang, X., Gong, P., Zhao, Y., Xu, Y., Cheng, X., Niu, Z., Luo, Z., Huang, H., Sun, F., Li, X. (2013): Water-level changes in China's large lakes determined from ICESat/GLAS data. - Remote Sensing of Environment 132: 131-144. DOI: 10.1016/j.rse.2013.01.005.

[36] Wen, B., Liu, X., Li, X., Yang, F., Li, X. (2012): Restoration and rational use of degraded saline reed wetlands: a case study in western Songnen Plain, China. - Chinese Geographical Science 22(2): 167-177. DOI: 10.1007/s11769-012-0519-z.

[37] Willekens, H., Chamnongpol, S., Davey, M., Schraudner, M., Langebartels, C., Van Montagu, M., Inze, D., Van Camp, W. (1997): Catalase is a sink for H2O2 and is indispensable for stress defence in C3 plants. - The EMBO journal 16(16): 4806-4816. DOI: $10.1093 / \mathrm{emboj} / 16.16 .4806$.

[38] Xi, L. L., Gou, Q. Q., Wang, G. H., Song, B. (2021): The responses of typical annual herbaceous plants to drought stress in a desert-oasis transition ecotone. - Acta Ecologica Sinica 41(13): 1-10.

[39] Xie, L., Wang, D. G. (2009a). Study on nitrogen removal performance in horizontal subsurface constructed wetland with Arundo donax var. versicolor. - Chinese Journal of Environmental Engineering 3(10): 1759-1762.

[40] Xie, L., Wang, D. G. (2009b). Treatment of domestic sewage by subsurface-flow constructed wetland with Arundo donax var. versicolor. - China Water \& Wastewater 25(5): 89-91.

[41] Xu, J., Tu, J. (2014): Physiology Research on waterlogging stress of four wetland plants. Northern Horticulture (04): 73-76.

[42] Xu, L. M., Cao, Y., Tang, S. W., Lu, Y. H., Luo, S. S., Ma, Y. S. (2020). Effects of drought stress and rewatering on physiological characteristics of Arundo donax var. versicolor. Science of Soil and Water Conservation 18(03): 59-66. DOI: 10.16843/j.sswc.2020.03.007.

[43] Xue, Y. Y., Luan, Z. Q., Shi, D., Yan, D. D. (2020): The influences of the hydraulic gradient on the ecological characteristics of wetland vegetation communities in Sanjiang Plain, Northeast China. - Journal of Nanjing Forestry University (Natural Sciences Edition) 44(06): 39-47.

[44] Yang, Y., Cao, Y., Zhang, S. J. (2015): Effects of Soil moisture regime on rhizomatic germination and young shoot growth of Carex cinerascen. - Journal of Ecology and Rural Environment 31(02): 180-187. DOI: 10.11934 / j.issn.1673-4831.2015.02.007.

[45] Ye, B. J., Li, C. L. (1994): Studies on the techniques and methods for tissue culture of Arundo donax var. versicolor. - Journal of Beijing Agricultural College 9(1): 48-52. DOI: 10. 13473 /j. cnki. issn. 1002-3186. 1994. 01. 010.

[46] Yin, S. B., Lyu, X. G., Wu, H. T. (2010): Some theoretic problems of wetland definition. - Wetland Science 8(02): 182-188. DOI: 10.13248/j.cnki.wet landsci.2010.02.008.

[47] Yu, H. B., Zeng, Q., Xiao, R. L., Yang, Z. J., Zhang, S. N., Zhao, Z. L. (2014): Analysis the diurnal dynamic of photosynthetic characteristics and its influencing factors on Arundo donax var. versicolor. - Journal of Hunan Agricultural University 39(2): 200-203. DOI: 10.3724/SP.J.1238.2013.00200.

[48] Zhang, J. T. (2011): Quantitative Ecology. - Science Press, Beijing. 
[49] Zhang, Q., Wang, H. Y., Cui, X. H. (2005): A preliminary study of the germination of Arundo donax var. versicolor by soaking in winter. - Journal of Southwest Agricultural University (Natural Science) 27(02): 248-251.

[50] Zhang, D. J., Zhang, Y. M., Tong, S. Z., Qi, Q., Wang, X. H., Lu, X. G. (2020): Growth and physiological responses of Carex schmidtii to water-level fluctuation. - Hydrobiologia 847(3): 967-981. DOI: 10.1007/s10750-019-04159-z.

[51] Zhao, H. X., Wu, S. H., Jiang, L. G. (2007): Review on recent advances in ecological threshold research. - Acta Ecologica Sinica 27(01): 338-345.

[52] Zhuang, J. J., Wang, X. B., Guo, H. (2020): Effects of independent planting and mixed planting of Arundo donax on lead accumulation. - Guihaia 40(02): 151-158. 